ISSN 0130-8521. Передгірне та гірське землеробство і тваринництво. 2021. Вип. 70 (2)

DOI: $10.32636 / 01308521.2021-(70)-2-12$

UDC 577.12:591.132.1/.2:636.086

A. V. SHELEVACH, candidate of agricultural sciences

Y. F. RIVIS, doctor of agricultural sciences

Institute of Agriculture of Carpathian Region of NAAS

Hrushevskoho street, 5, v. Obroshyne, Lviv district, Lviv region, 81115,

e-mail: 1059@i.ua

\title{
EXCHANGE OF PROTEIN AND NITROGEN COMPOUNDS IN THE BULLS WHEN FEEDING CELLULOSE-CONTAINED FEED
}

Metabolic processes in the body of cattle, in particular in the digestive tract of bulls, when feeding young grass, feed and various forms of fiber-containing feed during the spring-summer transition period are poorly understood. Young grass at this time contains a large amount of nitrogen-containing compounds, but very little readily available sugars and fiber. The content of the latter in the young grass of pastures and meadows, instead of the required for cattle $22-24 \%$ of dry matter, is only $15-18 \%$. In addition, the fiber of young grass has very little of its structured form (associated with lignin and hemicellulose). This leads to the fact that cattle do not fully use the nitrogen available in the young grass.

In the course of research we studied changes in the concentration of protein, residual and total nitrogen, urea, as well as the activity of transamination enzymes in whole blood of bulls depending on the time relative to the beginning of feeding and the presence in the diet of various forms of fiber.

It is shown that the activity of transamination enzymes (AST and ALT) under the action of various forms of fiber-containing food before morning feeding increases by $5,1-7,5 \%$ compared to control. This increase does not depend on the time relative to the start of feeding. It is suggested that the activity of transamination enzymes in the whole blood of bulls when feeding them fiber-containing feed is substrate regulated.

According to research, it can be argued that the activity of reamination enzymes in the blood serum of bulls during the feeding of fiber-containing feed before morning feeding increases by $6,4-8,5 \%$ compared to control. The concentration of protein in the blood serum of bulls, regardless of the time relative to the beginning of feeding, with the feeding of various forms of fiber-containing feed increases by 4,2-6,1\% compared to control. The content of urea and residual nitrogen in the whole blood of bulls at 3 hours from the beginning of morning feeding decreases by $6,3-8,9 \%$, and protein and total nitrogen - increases compared to control.

It is also shown that weight gain depends on the level of nitrogen-containing compounds and the activity of transamination enzymes in the blood serum of

(C) Shelevach A. V., Rivis Y. F., 2021 
experimental bulls.

Key words: bulls, blood serum, fiber-containing feed, protein, transamination enzymes.

\section{Шелевач А. В., Рівіс Й. Ф.}

Інститут сільського господарства Карпатського регіону НААН

Обмін протеїну i азотових сполук в організмі бугайців за згодовування клітковиновмісного корму

Обмінні процеси в організмі великої рогатої худоби, зокрема у травному каналі бугайців, при згодовуванні молодої трави, комбікорму та різних форм клітковиновмісного корму під час весняно-літнього перехідного періоду є маловивченими. Молода трава в цей час містить у своєму складі велику кількість азоту азотовмісних сполук, але дуже мало легкодоступних цукрів і клітковини. Вміст останньої у молодій траві пасовищ і луків, замість потрібних для великої рогатої худоби 22-24 \% від сухої речовини, становить всього 15-18 \%. Крім того, в клітковині молодої трави дуже мало іiі структуризованої форми (зв'язаної з лігніном і геміцелюлозою). Це призводить до того, що велика рогата худоба неповністю використовує наявний у молодій траві азот.

У ході виконання досліджень ми вивчили зміни вмісту протеїну, залишкового i загального азоту, сечовини, а також активність ензимів трансамінування у сироватці крові бугайців залежно від часу щодо початку годівлі і наявності у раціоні різних форм клітковиновмісного корму. Також було взято до уваги такий важливий показник азотового обміну у жуйних тварин, як рівень ізовалеріанової кислоти у рубцевій рідині.

За результатами досліджень можна стверджувати, що активність ензимів трансамінування (АСТ і АЛТ) у сироватці крові дослідних бугайців під дією згодовування різних форм клітковиновмісного корму після ранкової годівлі підвищується на 5,1-7,5 \% порівняно 3 контролем. Це підвищення залежить від часу щодо початку годівлі. Доведено, що активність ензимів трансамінування у сироватці крові бугайців при згодовуванні їм клітковиновмісного корму регулюється субстратно.

Вміст протеїну у сироватці крові бугайців після ранкової годівлі під дією клітковиновмісного корму з різною величиною частинок також зростає на 6,4-8,5 \% порівняно 3 контролем. Вміст сечовини і залишкового азоту у сироватці крові бугайців на третій годині після початку годівлі збільшується на 4,2-6,1 \%, а протеїну і загального азоту - на 6,3-8,9 \% порівняно 3 контролем.

Показано також, що рівень азотовмісних сполук і активність ензимів переамінування у сироватці крові дослідних бугайців позитивно корелюють 3 приростами їх маси тіла.

Ключові слова: сироватка крові, протеїн, клітковиновмісний корм, бугайці, ензими трансамінування. 
Introduction. Young grass contains insufficient fiber (only 15 $18 \%$, while $22-24 \%$ are needed) $[1,3,14-16]$. At the same time, it contains mainly easily digestible fiber [2-4], which is very quickly fermented in the rumen $[5,11,18]$. The consequence of this process is incomplete use of nutrients available in young grass [17], primarily nitrogen-containing compounds $[9,12]$, by ruminal microorganisms, which leads to lower levels of protein absorption in the body. It means, that diet of ruminants lacks structural fiber during spring-summer transition period. In particular, fiber associated with hemicelluloses and lignin.

In order to replenish the structural fiber in the diet of ruminants that consume young grass, they are fed natural or processed rough feed (hay or straw) [6-8]. Fiber-containing feed performs various functions in the gastrointestinal tract of ruminants: it acts as nutrient, adsorbent and surface for ruminal microorganisms [27, 10, 11].

Winter wheat straw contains mainly fiber, hemicellulose and polyuronides [13-16]. Therefore, its nutritional value is low [4, 5]. The data obtained by us indicate that its presence in the rumen of ruminants, it significantly affects the intensity of metabolic processes [13, 14]. The size of its particles determines the speed of passage of the rumenal content into the posterior parts of the gastrointestinal tract.

Structural fiber, hemicellulose a has a very low nutritional and energy value $[18,20]$. At the same time, it is able to adsorb and transport on its surface significant amounts of nutrients available later in the gastrointestinal tract of ruminants [19-24]. The surface of structural fiber is inhabited by a large number of microorganisms (bacteria and protozoa) $[25$, $26]$. They have cellulose-, amylo-, proteo- and lipolytic activity [10, 29]. As a result, ruminants significantly increase their supply of carbohydrates, lipids, biologically active substances (primarily water-soluble B vitamins) and nitrogen-containing compounds from the gastrointestinal tract into the blood and lymph [28, 31].

It is currently unknown which of the above functions of fibercontaining feed is more important for the body of a ruminant animal. In addition, the effect of various forms (in particular, particle sizes) of structural fiber-containing feed on various parts of metabolic processes in the body of ruminants remains unknown.

Based on this, the aim was to establish the dynamic patterns of changes in the content of ammonia, amine and protein nitrogen in the liquid fraction of the rumen, the content of basic nitrogen compounds and the activity of reamination enzymes in serum of fattening bulls. 
Materials and methods. On farm "Litynske" in Drohobych district of Lviv region were formed three groups of Simmental breed fattening bulls (5 animals each) using methodological approaches used in international practice in accordance with the requirements of ISO 17025, as well as in accordance with generally accepted methods of groups of analogues by age and live weight. Three animals from each group had rumenal fistulas. All animals were clinically healthy.

Under the conditions of tethered keeping, animals of the control group during May-July (90 days) received the basic ration (OR), which included young green mass of cereal and legume pasture $(35.0 \mathrm{~kg})$ and compound feed $(2.5 \mathrm{~kg})$.

Animals of the experimental groups in addition to the main diet were fed $1 \mathrm{~kg}$ of winter wheat straw, crushed into particles of different sizes. Animals of the I experimental group were fed straw chaff with a particle size of $0.2-2.0 \mathrm{~cm}$, and animals of the II experimental group $-3.0-5.0$ $\mathrm{cm}$. At the end of the experiment in fattening bulls from the jugular vein blood samples were taken before morning feeding and at 3 hours after its beginning. In bulls with rumenal fistulas, samples of its contents were taken before morning feeding, as well as at the $2 \mathrm{nd}$, 4th, 7 th and 10th hours after. In the liquid rumenal content it was determined the level of ammonia, amine and protein nitrogen according to Kjeldahl.

In the blood serum were determined levels of urea, residual and total nitrogen, protein and activity of reamination enzymes - aspartate aminotransferase (AST 2.6.1.1) and alanine amino transferase (ALT 2.7.1.2). Serum urea was determined by the Conway method; protein, residual and total nitrogen - according to Kjeldahl. The activity of AST and ALT in blood serum was determined by the methods described by V. V. Vlizlo et al. [9].

Biometric analysis of the results was performed by the method of variation statistics according to $\mathrm{N}$. A. Plokhinsky, taking into account the Student's criterion. Standard computer mathematical and statistical programs, in particular Microsoft EXCEL, were used to estimate the probability of the obtained results - arithmetic mean values (M), arithmetic mean error $( \pm \mathrm{m})$ and probability of differences between the studied arithmetic mean values $(\mathrm{P})$.

Results and discussion. It was found that in the liquid content of the rumen of bulls of experimental groups, which were fed young green mass of cereals, legumes, and fiber-containing feed with different particle sizes, the lowest content of ammonia nitrogen and amine nitrogen were before feeding and 10 hours after begin of feeding - by 24.5 and $34.2 \%$, 
respectively, in groups I and II compared with the control). The content of ammonia nitrogen and amine nitrogen in the liquid content of the rumen of bulls of the experimental groups increased on $2-4$ hours after the start of feeding. Moreover, it was maximum at 2 hours after the start of feeding, but 23.1 and $27.8 \%$ lower than in the control, what is showed in the Table 1.

The presence of amine nitrogen in the ruminal fluid indicates the presence of free amino acids. The large number of free amino acids in the ruminal fluid may be due to the low efficiency of their inclusion in proteins [18].

Feeding the bulls of the experimental groups of straw chaff with particles of different sizes, compared with the bulls of the control group, resulted in a $29.35 \%$ reduction in the content of ammonia nitrogen and amine nitrogen in the liquid content of the rumen. It was also found that, compared with the control, the content of ammonia nitrogen and amine nitrogen in the liquid fraction of the rumen of fattening bulls of the II experimental group, which in addition to the main diet were fed straw chaff with a particle size of $3.0-5.0 \mathrm{~cm}$ is minimal - by $34.7 \%$ lower. This is due to the fuller use of ammonia nitrogen and amine nitrogen to synthesize the main components of their cells by microorganisms inhabiting rumen [11].

The reliability of the above mentioned is also confirmed by the data on the content of protein nitrogen in the ruminal fluid of the experimental bulls. In particular, the lowest its level was in bulls of the I and II experimental groups, which were fed green mass of cereal and legume pastures plus fiber-containing feed. It was observed before feeding and at 10 hours after the start of feeding (6.4 and $8.7 \%$ less compared to control). The amount of protein nitrogen in the fluid of the rumen of bulls of the II experimental group decreased by 2-7 hours after the start of feeding by 7.9 and $9.1 \%$, respectively, compared with the control.

Feeding bulls of I and II experimental groups of straw chips with a particle size of 0.2-2.0 and 3.0-5.0 cm, respectively, compared with bulls of the control group, led to an increase in the amount of protein nitrogen in their ruminal fluid by 7-10th hour after the start of feeding (8.1 and 9.5\% more than control). It should be noted that in the ruminal fluid of bulls of I and II experimental groups, compared with bulls of the control group, the amount of protein nitrogen decreased by 2-4th and 4th hour after the start of morning feeding by 6.9 and $7.5 \%$, respectively. 
ISSN 0130-8521. Передгірне та гірське землеробство і тваринництво. 2021. Вип. 70 (2)

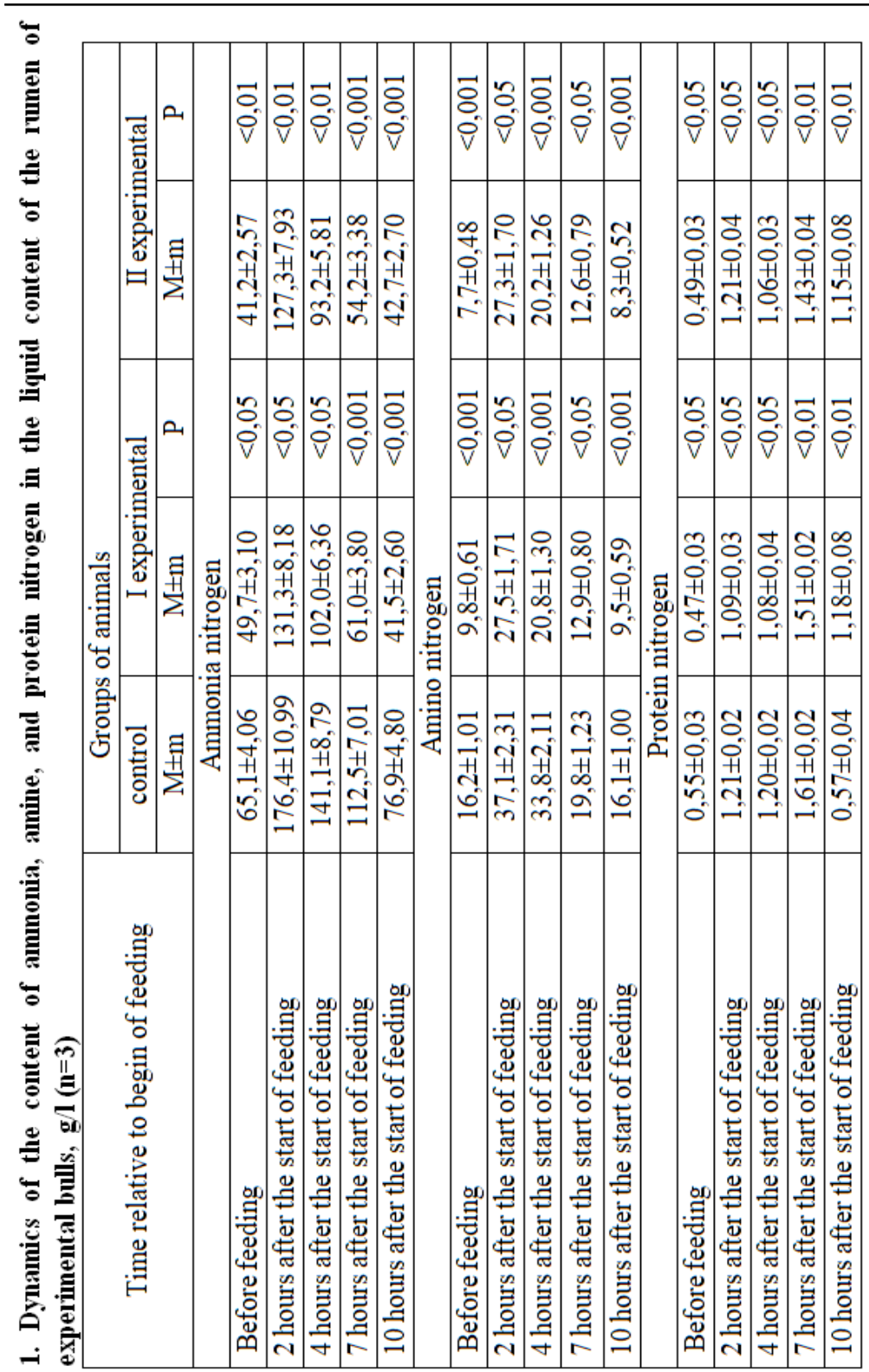


Such differences in the content of protein nitrogen in the cicatricial fluid of bulls depending on the time relative to the beginning of feeding are associated not only with the direction of metabolic processes in the rumen, but also with the intensity of absorption and evacuation to the posterior gastrointestinal tract of ruminants.

The results of the analysis of Table 2 show that the content of urea and residual nitrogen in the serum of fattening bulls of experimental groups, fed different forms of fiber-containing feed, compared with bulls of the control group who received the basic diet, before morning feeding has only a tendency to decrease.

2. The content of nitrogen-containing compounds and the activity of reamination enzymes in the serum of experimental bulls, $M \pm m, n=5$

\begin{tabular}{|c|c|c|c|}
\hline \multirow{2}{*}{ Indicators } & \multicolumn{3}{|c|}{ Groups of animals } \\
\hline & control & I experimental & II experimental \\
\hline \multicolumn{4}{|c|}{ Before feeding } \\
\hline Protein, $g / 1$ & $70,91 \pm 1,71$ & $85,62 \pm 1,75^{* *}$ & $89,15 \pm 1,9 * * *$ \\
\hline AST, units/1 & $61,08 \pm 1,41$ & $57,43 \pm 0,52 * *$ & $58,23 \pm 0,86^{* *}$ \\
\hline ALT, units/l & $47,97 \pm 1,87$ & $38,69 \pm 1,77 * *$ & $38,81 \pm 0,92 * *$ \\
\hline Urea, $\mu \mathrm{mol} / 1$ & $3,66 \pm 0,25$ & $2,83 \pm 0,27 *$ & $2,66 \pm 0,19 * *$ \\
\hline $\begin{array}{l}\text { Residual nitrogen, } \\
\mathrm{g}^{-3 / 1}\end{array}$ & $0,28 \pm 0,02$ & $0,23 \pm 0,01$ & $0,21 \pm 0,01$ \\
\hline Total nitrogen, $g^{-3} / 1$ & $26,69 \pm 0,39$ & $27,45 \pm 0,25$ & $27,11 \pm 0,17$ \\
\hline \multicolumn{4}{|c|}{3 hours after the start of feeding } \\
\hline Protein, $g / 1$ & $71,82 \pm 1,71$ & $78,3 \pm 1,07 * *$ & $79,6 \pm 1,38^{* *}$ \\
\hline AST, units/l & $67,25 \pm 2,21$ & $79,73 \pm 1,98^{* * *}$ & $78,81 \pm 2,23$ *** \\
\hline ALT, units/l & $49,36 \pm 1,35$ & $54,91 \pm 0,81^{*}$ & $56,32 \pm 1,54 * *$ \\
\hline Urea, $\mu \mathrm{mol} / \mathrm{l}$ & $5,33 \pm 0,15$ & $5,16 \pm 0,18$ & $4,99 \pm 0,11 *$ \\
\hline $\begin{array}{l}\text { Residual nitrogen, } \\
\mathrm{g}^{-3} / 1\end{array}$ & $0,38 \pm 0,02$ & $0,46 \pm 0,01 * *$ & $0,45 \pm 0,01 * *$ \\
\hline Total nitrogen, $\mathrm{g}^{-3} / 1$ & $25,61 \pm 0,16$ & $28,25 \pm 0,18^{*}$ & $29,43 \pm 0,12 * *$ \\
\hline
\end{tabular}

Note: changes are probable, $\mathrm{p}<0,05^{*} ; \mathrm{p}<0,01 * * ; \mathrm{p}<0,001^{* * * *}$

At the same time, the level of protein in their blood increases. In this case, the content of total nitrogen before feeding has only a tendency to increase. This is due to both the level of their entry into the blood from the gastrointestinal tract and the transformations in the liver. After all, the results of studies indicate that the activity of reamination enzymes (AST and ALT) in the serum of bulls of experimental groups, compared with 
bulls of the control group, after morning feeding increases by $5.1-7.5 \%$. It is obvious that the change in the activity of reamination enzymes (AST and ALT) in the serum is associated with the level of nitrogen-containing compounds incoming from the gastrointestinal tract into the blood [12]. The above data is confirmed by the indicators obtained 3 hours after the start of morning feeding. At this time, it is observed the maximum changes in the level of nutrients incoming from the gastrointestinal tract into the blood, as indicated by other authors [4].

Metabolic processes in the body of experimental bulls affect their productivity, as evidenced by changes in the activity of enzymes of reamination and fluctuations in urea, residual nitrogen, protein and total nitrogen in the serum. Thus, the absolute weight gain of bulls of the control group during the experiment was $64.4 \pm 1.08 \mathrm{~kg}$, and bulls of I and II experimental groups $-76.9 \pm 1.69(\mathrm{p}<0.001)$ and $72.7 \pm 1.60 \mathrm{~kg}(\mathrm{p}<0,01)$, which is 19.4 and $12.9 \%$ more compared to the control group.

Higher weight gain of bulls of experimental group I compared with bulls of experimental group II is associated with the time during which the fiber-containing food was in the rumen and, consequently, with the level of nutrients incoming from the gastrointestinal tract into the blood and tissues. Smaller particles of fiber-containing feed pass faster from the rumen to the lower parts of the gastrointestinal tract of ruminants compared to larger particles [5]. This significantly affects the level of digested nutrients of the feed and assimilated from the gastrointestinal tract into the blood and tissues as well as content of individual components and the activity of reamination enzymes.

Conclusions. It was found that different forms of fiber-containing feed, depending on the time relative to the beginning of feeding, affect the metabolic processes in the rumen and the level of nitrogen-containing compounds incoming from the gastrointestinal tract into the blood of experimental bulls. Thus, fiber-containing feed has an effect on the substrate regulation of enzyme activity in ruminants.

The activity of reamination enzymes (AST and ALT) in the serum of bulls during the feeding of fiber-containing feed at 3 hours after the start of morning feeding increases by $5.1-7.5 \%$ compared with the control.

The protein content in the serum of experimental bulls, after morning feeding under the action of fiber-containing food with different particle sizes also increases by $6.4-8.5 \%$ compared to the control.

The content of urea and residual nitrogen in the serum of bulls before morning feeding under the action of fiber-containing food with different particle sizes is reduced by $6.1-7.8 \%$ compared with the control. The 
content of protein, residual and total nitrogen in the serum of bulls on the third hour after the start of feeding increases by $4.2-6.1 \%$, and level of urea - decreases by $6.3-8.9 \%$ compared with the control.

\section{Список використаної літератури}

1. Алиев А. А. Достижения физиологии пищеварения сельскохозяйственных животных в XX веке. Сельскохозяйственная биология. 2007. № 2. C. 12-13.

2. Лабораторні методи досліджень у біології, тваринництві та ветеринарній медицині : довідник / В. В. Влізло та ін. ; за ред. В. В. Влізла. Львів. 2012. 759 с.

3. Спосіб підвищення продуктивності відгодівельної худоби та покращення якості яловичини : пат. 31351 Україна. № 201104241 ; Рівіс Й. Ф., Шелевач А. В. Власник: ІСГКР НААН України. Заявл. 09.04.2010 ; опубл. 25.02.2011, Бюл. № 8 (кн. 2). 114 с.

4. Шелевач А. В. Динаміка концентрації летких жирних кислот у рубці бугайців за згодовування різних форм клітковиновмісного корму. Біологія тварин. 2011. Вип. 58. С. 31-39.

5. Шелевач А. В. Обмінні процеси в організмі бугайців та їх корекція різними формами клітковиновмісного корму. Вісник біологічного факультету ЛНУ імені I. Франка. 2011. Вип. 47. С. 15-24.

6. Bhat S. K., Wallace R. J., Orskov E. R. Study of the relation between straw quality and its colonization by rumen microorganisms. J. of Agric. Sci. 2014. Vol. 110. P. 561-565.

7. Brown W. F., Kunkle W. E. Improving the Feeding Value of Hay and Straw by Anhydrous Ammonia Treatment. J. of Anim. Sci. 2013. V. 12. P. 17-25.

8. Chalupa W. Degradation of amino acids by the mixed rumen microbial population. J. Anim. Sci. 2017. Vol. 43. P. 828-834.

9. Chaplin R. Experiments in straw handling. J. Agric. Sci. 2017. Vol. 178. P. 1130 .

10. Demeyer D., Van Nevel C. Influence of substrate and microbial interaction on

\section{References}

1. Aliev A. A. Achievements in the physiology of digestion of agricultural animals in the twentieth century. Sel'skohozjajstvennaja biologija. 2007. No 2. P. 12-13.

2. Laboratory research methods in biology, animal husbandry and veterinary medicine : textbook / V. V. Vlizlo et al. ; za red. V. V. Vlizla. Lviv, 2012. 759 p.

3. A method of increasing the productivity of fattening cattle and improving the quality of beef : pat. 31351 Ukraina. № 201104241 ; Rivis Y. F., Shelevach A. V. Vlasnyk: ISHKR NAAN Ukrainy. Zaiavl. 09.04.2010 ; opubl. 25.02.2011, Biul. No 8 (kn. 2). 114 p.

4. Shelevach A. V. Dynamics of the concentration of volatile fatty acids in the rumen of bulls for feeding different forms of fiber-containing feed. Biolohiia tvaryn. 2011. Issue 58. P. 31-39.

5. Shelevach A. V. Metabolic processes in the body of bulls and their correction by various forms of fiber-containing feed. Visnyk biolohichnoho fakultetu LNU imeni I. Franka. 2011. Issue 47. P. 15-24.

6. Bhat S. K., Wallace R. J., Orskov E. R. Study of the relation between straw quality and its colonization by rumen microorganisms. J. of Agric. Sci. 2014. Vol. 110. P. 561-565.

7. Brown W. F., Kunkle W. E. Improving the Feeding Value of Hay and Straw by Anhydrous Ammonia Treatment. J. of Anim. Sci. 2013. Vol. 12. P. 17-25.

8. Chalupa W. Degradation of amino acids by the mixed rumen microbial population. J. Anim. Sci. 2017. Vol. 43. P. 828-834.

9. Chaplin R. Experiments in straw handling. J. Agric. Sci. 2017. Vol. 178. P. 1130.

10. Demeyer D., Van Nevel C. Influence of substrate and microbial interaction on 
rumen microbial growth. Reprod. Nutr. Dev. 2009. Vol. 26. P. 161-179.

11. Doig B. Beef Cow Rations and Winter Feeding Guidelines. J. Agric. Sci. 2019. Vol. 15. P. 102-109.

12. Febel H., Fekete S. Factors influencing microbial growth and the efficiency of microbial protein synthesis. Acta Vet. Hung. 2017. Vol. 44 (1). P. 39-56.

13. Firkins J. Maximizing microbial protein synthesis in the rumen. J. Nutr. 2019. Vol. 126 (4). P. 1347-1354.

14. Fondevila M., Dehority B. Interactions between Fibrobacter succinogenes, Prevotella ruminicola, and Ruminococcus flavefaciens in the digestion of cellulose from forages. J. Anim. Sci. 2007. Vol. 74 (3). P. 678-684.

15. Givens D. Nutritional characterisation of forages. Grass Farmer. 2007. Vol. 55. P. 10 .

16. Huntington G., Zetina E., Whitt J. Effects of dietary concentrate level on nutrient absorption, liver metabolism, and urea kinetics of beef steers fed isonitrogenous and isoenergetic diets. J. Anim. Sci. 2010. Vol. 74 (4). P. 908-916.

17. Junqin Chen, Paul Weimer J. Competition among three predominant ruminal cellulolytic bacteria in the absence or presence of non-cellulolytic bacteria. Microbiology. 2011. Vol. 147. P. 21-30.

18. Kijora C., Simon O., Jacobi U. Nitrogen metabolism in the large intestine of ruminants. 3. Microbial utilization of intracecally administered $14 \mathrm{C}$ - and $15 \mathrm{~N}$ marked urea. Arch. Tierernahr. 2016. Vol. 36 (9). P. 839-850.

19. Lough A., Smith A. Influence of the products of phospholipolysis of phosphatidylcholine on micellar solubilization of fatty acids in the presence of bile salts in ruminal animals. Brit. J. of Nutr. 2016. Vol. 35. P. 89-96.

20. Luchini N., Broderick G., Combs D. In vitro determination of ruminal protein degradation using freeze-stored ruminal microorganisms. J. Anim. Sci. 2014. Vol. 74 (10). P. 2488-2499.

21. Ludden P. A., Wechter T. L., Hess B. rumen microbial growth. Reprod. Nutr. Dev. 2009. Vol. 26. P. 161-179.

11. Doig B. Beef Cow Rations and Winter Feeding Guidelines. J. Agric. Sci. 2019. Vol. 15. P. 102-109.

12. Febel H., Fekete S. Factors influencing microbial growth and the efficiency of microbial protein synthesis. Acta Vet. Hung. 2017. Vol. 44 (1). P. 39-56.

13. Firkins J. Maximizing microbial protein synthesis in the rumen. J. Nutr. 2019. Vol. 126 (4). P. 1347-1354.

14. Fondevila M., Dehority B. Interactions between Fibrobacter succinogenes, Prevotella ruminicola, and Ruminococcus flavefaciens in the digestion of cellulose from forages. J. Anim. Sci. 2007. Vol. 74 (3). P. 678-684.

15. Givens D. Nutritional characterisation of forages. Grass Farmer. 2007. Vol. 55. P. 10.

16. Huntington G., Zetina E., Whitt J. Effects of dietary concentrate level on nutrient absorption, liver metabolism, and urea kinetics of beef steers fed isonitrogenous and isoenergetic diets. J. Anim. Sci. 2010. Vol. 74 (4). P. 908-916.

17. Junqin Chen, Paul Weimer J. Competition among three predominant ruminal cellulolytic bacteria in the absence or presence of non-cellulolytic bacteria. Microbiology. 2011. Vol. 147. P. 21-30.

18. Kijora C., Simon O., Jacobi U. Nitrogen metabolism in the large intestine of ruminants. 3. Microbial utilization of intracecally administered $14 \mathrm{C}$ - and $15 \mathrm{~N}$ marked urea. Arch. Tierernahr. 2016. Vol. 36 (9). P. 839-850.

19. Lough A., Smith A. Influence of the products of phospholipolysis of phosphatidylcholine on micellar solubilization of fatty acids in the presence of bile salts in ruminal animals. Brit. J. of Nutr. 2016. Vol. 35. P. 89-96.

20. Luchini N., Broderick G., Combs D. In vitro determination of ruminal protein degradation using freeze-stored ruminal microorganisms. J. Anim. Sci. 2014. Vol. 74 (10). P. 2488-2499.

21. Ludden P. A., Wechter T. L., Hess B. 
W. Effects of oscillating dietary protein on nutrient digestibility, nitrogen metabolism, and gastrointestinal organ mass in sheep. $J$. Anim. Sci. 2019. Vol. 80. P. 3021-3026.

22. Michalet-Doreau B., Fernandez I., Fonty G. A. comparison of enzymatic and molecular approaches to characterize the cellulolytic microbial ecosystems of the rumen and the cecum. J. Anim. Sci. 2012. Vol. 80. P. 790-796.

23. Miron J., Ben-Ghedalia D., Morrison M. Adhesion Mechanisms of Rumen Cellulolytic Bacteria in Bulls. J. Dairy Sci. 2010. Vol. 84. P. 1294-1309.

24. Mosoni P., Fonty G., Gouet P. Competition Between Ruminal Cellulolytic Bacteria for Adhesion to Cellulose. Current Microbiology. 1997. Vol. 35, № 1. P. 44-47.

25. Nelson K., Nelson B. Why Feed Straw? Dairy Nutrition and Management. 2003. Vol. 3. P. 14-19.

26. Pitt R., Van Kessel J., Fox D. Prediction of ruminal volatile fatty acids and $\mathrm{pH}$ within the net carbohydrate and protein system. J. Anim. Sci. 2015. Vol. 74 (1). P. 226-244.

27. Supplementation of Ammoniated Wheat Straw in Wintering Diets of Gestating Beef Cows / Cunningham F. et al. Kansas State University Journal. 2004. Vol. 17. P. 112-120.

28. Ulbrich M., Hoffmann M., Baumeier A. Urea utilization in growing lambs. 4. N balances with unprocessed rations. Arch. Tierernahr. 2019. Vol. 36 (8). P. 697-707.

29. Volpe J., Vagelos P. Mechanisms and regulation of biosynthesis of saturated fatty acids. Physiol. Rev. 2018. Vol. 56. P. 339417.

30. Walt J., Briel B. Volatile fatty acid metabolism in sheep. 1. Average daily volatile fatty acid production in the rumen of sheep fed lucerne hay. J. Vet. Res. 2017. Vol. 43 (1). P. 11-21.

31. Wells J., Russell J. Why do many ruminal bacteria die and lyse so quickly. $J$. Dairy Sci. 2007. Vol. 79 (8). P. 1487-1495.
W. Effects of oscillating dietary protein on nutrient digestibility, nitrogen metabolism, and gastrointestinal organ mass in sheep. $J$. Anim. Sci. 2019. Vol. 80. P. 3021-3026.

22. Michalet-Doreau B., Fernandez I., Fonty G. A. comparison of enzymatic and molecular approaches to characterize the cellulolytic microbial ecosystems of the rumen and the cecum. J. Anim. Sci. 2012. Vol. 80. P. 790-796.

23. Miron J., Ben-Ghedalia D., Morrison M. Adhesion Mechanisms of Rumen Cellulolytic Bacteria in Bulls. J. Dairy Sci. 2010. Vol. 84. P. 1294-1309.

24. Mosoni P., Fonty G., Gouet P. Competition Between Ruminal Cellulolytic Bacteria for Adhesion to Cellulose. Current Microbiology. 1997. Vol. 35, No 1. P. 44-47.

25. Nelson K., Nelson B. Why Feed Straw? Dairy Nutrition and Management. 2003. Vol. 3. P. 14-19.

26. Pitt R., Van Kessel J., Fox D. Prediction of ruminal volatile fatty acids and $\mathrm{pH}$ within the net carbohydrate and protein system. J. Anim. Sci. 2015. Vol. 74 (1). P. 226-244.

27. Supplementation of Ammoniated Wheat Straw in Wintering Diets of Gestating Beef Cows / Cunningham F. et al. Kansas State University Journal. 2004. Vol. 17. P. 112-120.

28. Ulbrich M., Hoffmann M., Baumeier A. Urea utilization in growing lambs. 4. N balances with unprocessed rations. Arch. Tierernahr. 2019. Vol. 36 (8). P. 697-707.

29. Volpe J., Vagelos P. Mechanisms and regulation of biosynthesis of saturated fatty acids. Physiol. Rev. 2018. Vol. 56. P. 339417.

30. Walt J., Briel B. Volatile fatty acid metabolism in sheep. 1. Average daily volatile fatty acid production in the rumen of sheep fed lucerne hay. J. Vet. Res. 2017. Vol. 43 (1). P. 11-21.

31. Wells J., Russell J. Why do many ruminal bacteria die and lyse so quickly. $J$. Dairy Sci. 2007. Vol. 79 (8). P. 1487-1495.

Received 23.07.2021 